\title{
Cow, Farm, and Herd Management Factors in the Dry Period Associated with Raised Somatic Cell Counts in Early Lactation
}

\author{
M. J. Green, ${ }^{*}{ }^{1}$ A. J. Bradley, $\ddagger$ G. F. Medley,§ and W. J. Browne‡ \\ *School of Veterinary Medicine and Science, University of Nottingham, Sutton Bonington Campus, Sutton Bonington, LE12 5RD \\ †School of Mathematical Sciences, University of Nottingham, Nottingham, NG7 2RD, UK \\ ‡Department of Clinical Veterinary Science, University of Bristol, Langford House, Langford, Bristol, BS40 5DT, UK \\ §Ecology and Epidemiology Group, Department of Biological Sciences, University of Warwick, Coventry, CV4 7AL, UK
}

\section{ABSTRACT}

This study investigated cow characteristics, farm facilities, and herd management strategies during the dry period to examine their joint influence on somatic cell counts (SCC) in early lactation. Data from $52 \mathrm{com}$ mercial dairy farms throughout England and Wales were collected over a 2-yr period. For the purpose of analysis, cows were separated into those housed for the dry period (6,419 cow-dry periods) and those at pasture $(7,425$ cow-dry periods). Bayesian multilevel models were specified with 2 response variables: $\ln$ SCC (continuous) and SCC $>199,000$ cells $/ \mathrm{mL}$ (binary), both within $30 \mathrm{~d}$ of calving. Cow factors associated with an increased SCC after calving were parity, an SCC $>199,000$ cells $/ \mathrm{mL}$ in the $60 \mathrm{~d}$ before drying off, increasing milk yield 0 to $30 \mathrm{~d}$ before drying off, and reduced DIM after calving at the time of SCC estimation. Herd management factors associated with an increased SCC after calving included procedures at drying off, aspects of bedding management, stocking density, and method of pasture grazing. Posterior predictions were used for model assessment, and these indicated that model fit was generally good. The research demonstrated that specific dry-period management strategies have an important influence on SCC in early lactation.

Key words: mastitis, somatic cell count, dry period, Bayesian multilevel model

\section{INTRODUCTION}

Somatic cell counts in milk are commonly used as indicators of mammary health on the basis that they reflect an immune response and therefore the presence of infection in the mammary gland. An SCC $<100,000$ cell $\mathrm{s} / \mathrm{mL}$ is reported to be normal in a healthy mammary gland (Sordillo et al., 1997), whereas an SCC >200,000

Received August 17, 2007.

Accepted December 19, 2007.

${ }^{1}$ Corresponding author: martin.green@nottingham.ac.uk
cells/mL is suggestive of bacterial infection (Brolund, 1985; Dohoo and Leslie, 1991; Schepers et al., 1997). Whereas the greatest variation in SCC results from the presence or absence of an infection, a number of other factors influence variability including parity, stage of lactation, time of day, and season of the year (Dohoo and Meek, 1982; Laevens et al., 1997; Schepers et al., 1997; Green et al., 2006). A threshold of 200,000 cells/ $\mathrm{mL}$ in composite milk from all 4 quarters provides a useful guideline for the likely presence of an IMI in at least 1 quarter, with a sensitivity and specificity of approximately 70\% (McDermott et al., 1982; Dohoo and Leslie, 1991; Schepers et al., 1997).

Changes in SCC across a threshold have been used to estimate the occurrence of new IMI (Cook et al., 2002; Schukken et al., 2003; Bradley and Green, 2005). This concept has been extended to the dry period, and SCC changes from below to above 200,000 cells $/ \mathrm{mL}$ between the end of one lactation and the start of the next lactation are suggestive of a new dry period IMI (Bradley et al., 2002; Cook et al., 2002; Bradley and Green, 2005). A study on a selection of Wisconsin dairy herds indicated that there was large between-herd variation in the proportion of cows that undergo SCC changes across the dry period, and the authors proposed that on-farm factors may be important in explaining these differences (Cook et al., 2002). Similarly, studies of dry period IMI using milk culture have identified differences in patterns of IMI during the dry period between farms and over time (Dingwell et al., 2004; Green et al., 2005). Causes of variability in the risk of infection during the dry period between farms are likely to be an important aspect of mastitis control but to date have been poorly quantified (Huijps and Hogeveen, 2007).

Management practices, including some dry period policies, have been found to influence the magnitude of herd SCC throughout lactation (McDougall, 2003; Barnouin et al., 2004; Lievaart et al., 2007; Wenz et al., 2007). With respect to SCC in early lactation, most research has focused on parity one cows and early lactation SCC has been found to be affected by different 


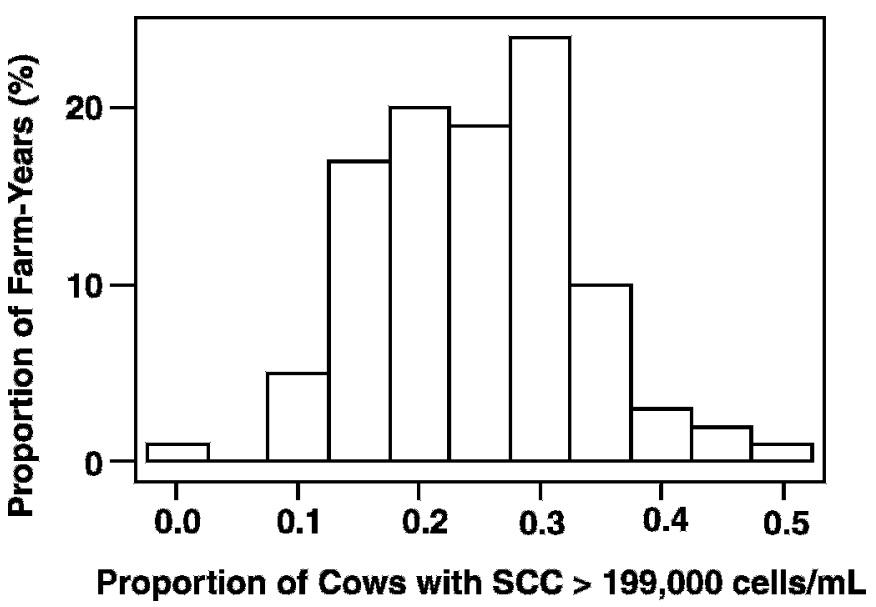

Figure 1. Proportion of cows in a farm-year with SCC $>199,000$ cell $/ \mathrm{mL}$ in the first $30 \mathrm{~d}$ of lactation, for each of 102 farm years, for cattle housed during the dry period.

aspects of precalving management (De Vliegher et al., 2004b; Svensson et al., 2006). An increased SCC early in the first lactation is of importance because it has been associated with an increased risk of culling, raised SCC, and reduced milk production later in that lactation (De Vliegher et al., 2004a, 2005a,b).

The purpose of this research was to investigate concurrently heifer and dry period management in relation to SCC in early lactation. Specific focus was on the joint influences of cow characteristics, farm facilities, and herd management strategies on SCC within $30 \mathrm{~d}$ of calving. A similar approach has recently been used to identify dry period determinants of the rate of clinical mastitis in early lactation in UK dairy herds (Green et al., 2007a).

\section{MATERIALS AND METHODS}

The data used for this research have been described in detail previously (Green et al., 2007a), and a brief outline is provided.

\section{Farm Selection}

Fifty-two commercial dairy farms located throughout England and Wales were included in the study over a 2 -yr period. This cohort was selected following participation in an earlier research project (Green et al., 2007b) and were known to have heterogeneity in the proportion of cows with SCC $>199,000$ cells $/ \mathrm{mL}$ in the first monthly recording of lactation (Figures 1 and 2). During the study period, the median herd size was 156 cows (minimum $=55$, maximum $=321$ ), and the median milk yield 8,500 $\mathrm{kg}$ per cow per year $($ mean $=8,215$

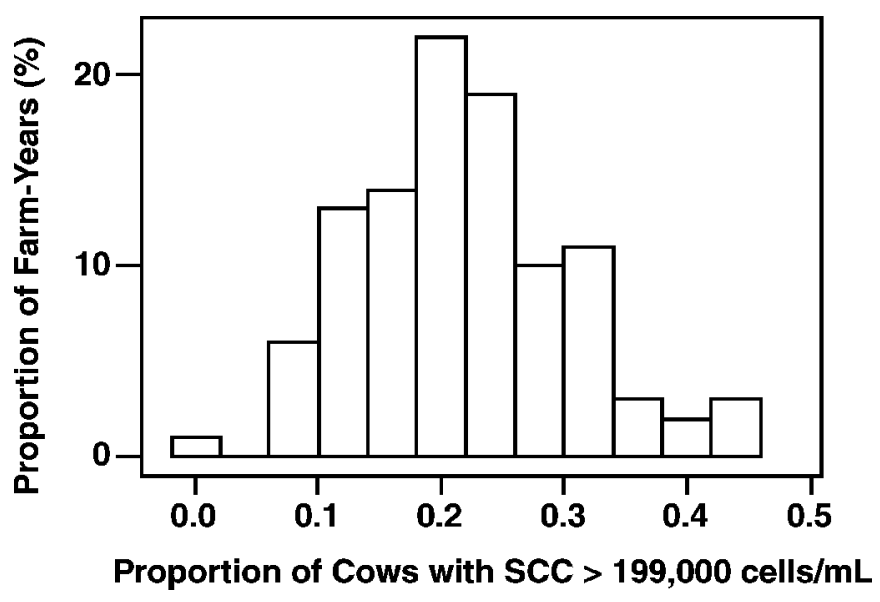

Figure 2. Proportion of cows in a farm year with SCC $>199,000$ cell $/ \mathrm{mL}$ in the first $30 \mathrm{~d}$ of lactation, for each of 104 farm years, for cattle at pasture during the dry period.

$\mathrm{kg}$, standard deviation $=1,115 \mathrm{~kg}$ ). The median rolling annual bulk milk somatic cell count was 198,000 cells/ $\mathrm{mL}$. The vast majority of cows were Holstein-Friesian breed; 46 farms were composed entirely of HolsteinFriesians, 3 farms were composed of Holstein-Friesians with fewer than $2 \%$ other breeds (Jersey, Guernsey, Shorthorn, Brown Swiss, and cross breeds), and 3 farms were composed of Holstein-Friesians with between 10 and 33\% other breeds (Jersey, Guernsey, Shorthorn, Brown Swiss, and cross breeds). There were insufficient numbers of different breeds to make between-breed comparisons. In 100 out of 104 farm-years in the study, dry cow treatments were used for all cows (but not for heifers prior to the first calving), and in the remaining 4 farm-years dry cow treatments were used for most cows (but not for heifers before the first calving) with occasional cows being missed. In 41 farm-years, the dry cow treatments were all antibiotic dry cow therapies, and in 63 farm-years, an internal teat sealant was used for cows with a low cell count before drying off (the SCC threshold being defined by the individual farm) with antibiotic dry cow therapy administered to other cows. No herds used the strategy of purposely omitting dry cow treatments for selected groups of cows, and therefore the effect of "no dry cow treatment" was not assessed. Information on dry cow products and product selection criteria was obtained from farm records and farmer interviews.

\section{Description of the Data}

Data were collected from all farms by trained researchers over a 2-yr period, May 2003 to May 2005. To characterize farm facilities and management policies, data were obtained from farmer interviews and through 


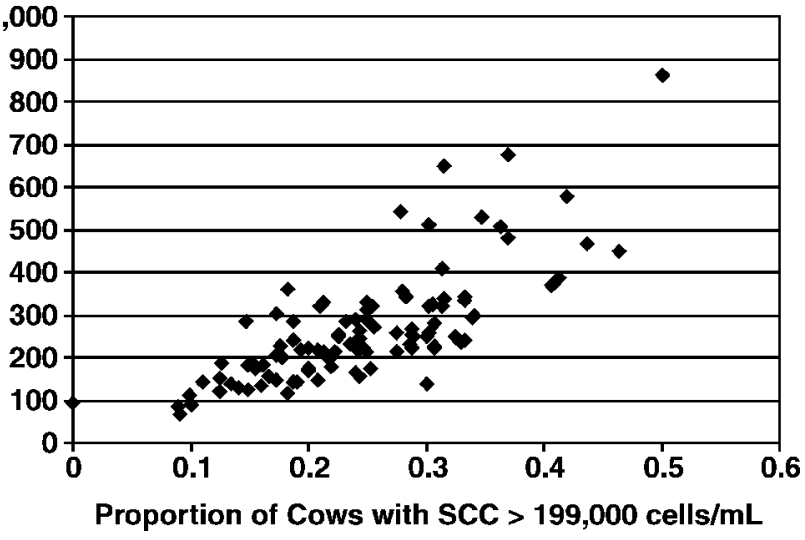

Figure 3. Scatter plot of the proportion of cows with SCC $>199,000$ cell $/ \mathrm{mL}$ and the arithmetic mean herd SCC, in the first $30 \mathrm{~d}$ of lactation, for 102 farm years when cattle were housed during the dry period.

on-farm observation, using structured, pretested questionnaires. Information from questionnaires was collected in May or June 2004 (for yr 1) and again in May or June 2005 (for yr 2). The information collected was in the following categories: general farm information (e.g., herd size, milk yield), protocols for any vaccinations administered (both for mastitis and other diseases), staff quantity and work patterns, cow groups and dates of movement between groups (including length of dry period), bedding (types, storage, quantities used, and methods of application and clean out), cow nutrition and water, procedures used for drying off (including products used, selection criteria for using teat

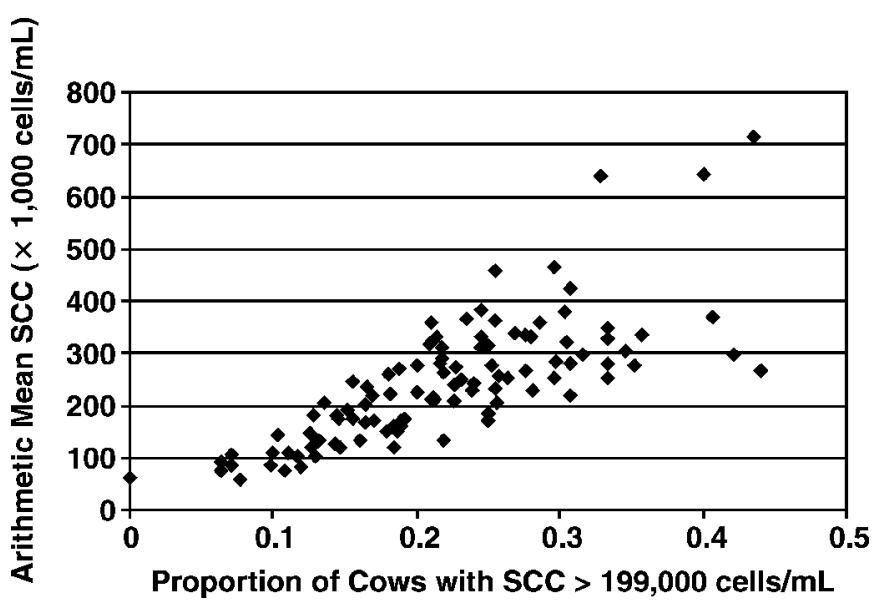

Figure 4. Scatter plot of the proportion of cows with SCC $>199,000$ cell/mL and the arithmetic mean herd SCC, in the first $30 \mathrm{~d}$ of lactation, for 104 farm years when cattle were at pasture during the dry period.
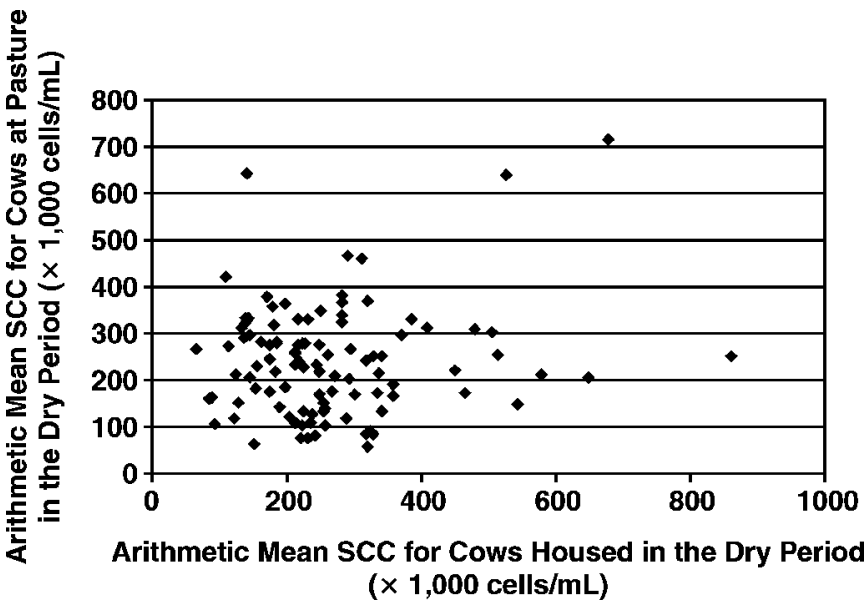

Figure 5. Scatter plot of the arithmetic mean herd SCC in the first $30 \mathrm{~d}$ of lactation, for cattle housed and at pasture, for 102 farmyears of the study ( 2 farm-years omitted with no housed dry periods available).

sealants if applicable, and methods of application), details of dry cow housing and pasture management, calving cow housing management, management procedures for calving, and recently calved cows and methods of fly control. Because heifers were generally kept separately from older cows, information relating solely to heifers or solely to older cows was included in the analysis but categorized as not applicable when appropriate for different parities. Parity was defined for each cow as the number of parturitions at the time of SCC estimation in the first $30 \mathrm{~d}$ of lactation, and thus heifers calving for the first time were defined as parity one cows. If a management policy changed during the year, the date of the change was recorded and the appropriate data used for each cow. Approximately 350 pieces of information were collected relating to each cow-dry period.

Cow information was obtained from a national milk recording body (National Milk Records, Chippenham, UK). Dates of calving, milk recording, and drying off were collated as well as parity, milk yield, and milk constituents. Somatic cell counts were estimated using the MilkoScan FT6000 (Foss Britain \& Ireland, Birchwood, Warrington, UK). Cows included in the analysis were dried off after May 2003 and calved before May 2005 . To be eligible for analysis, cows were required to have a somatic cell count estimated in a $30-d$ period after calving. Recordings in the first $4 \mathrm{~d}$ after calving were excluded (few cows had an SCC estimation at this time). Cows could calve twice in the 2 -yr period and thus have 2 dry periods and 2 postcalving SCC included in the study. Analysis was conducted separately for cows housed during the dry period and for those at pasture during the dry period because different sets of 
Table 1. Parameter estimates from the multilevel model with $\log (\mathrm{SCC} / 1,000)$ as the response, for cows housed during the dry period (model 1)

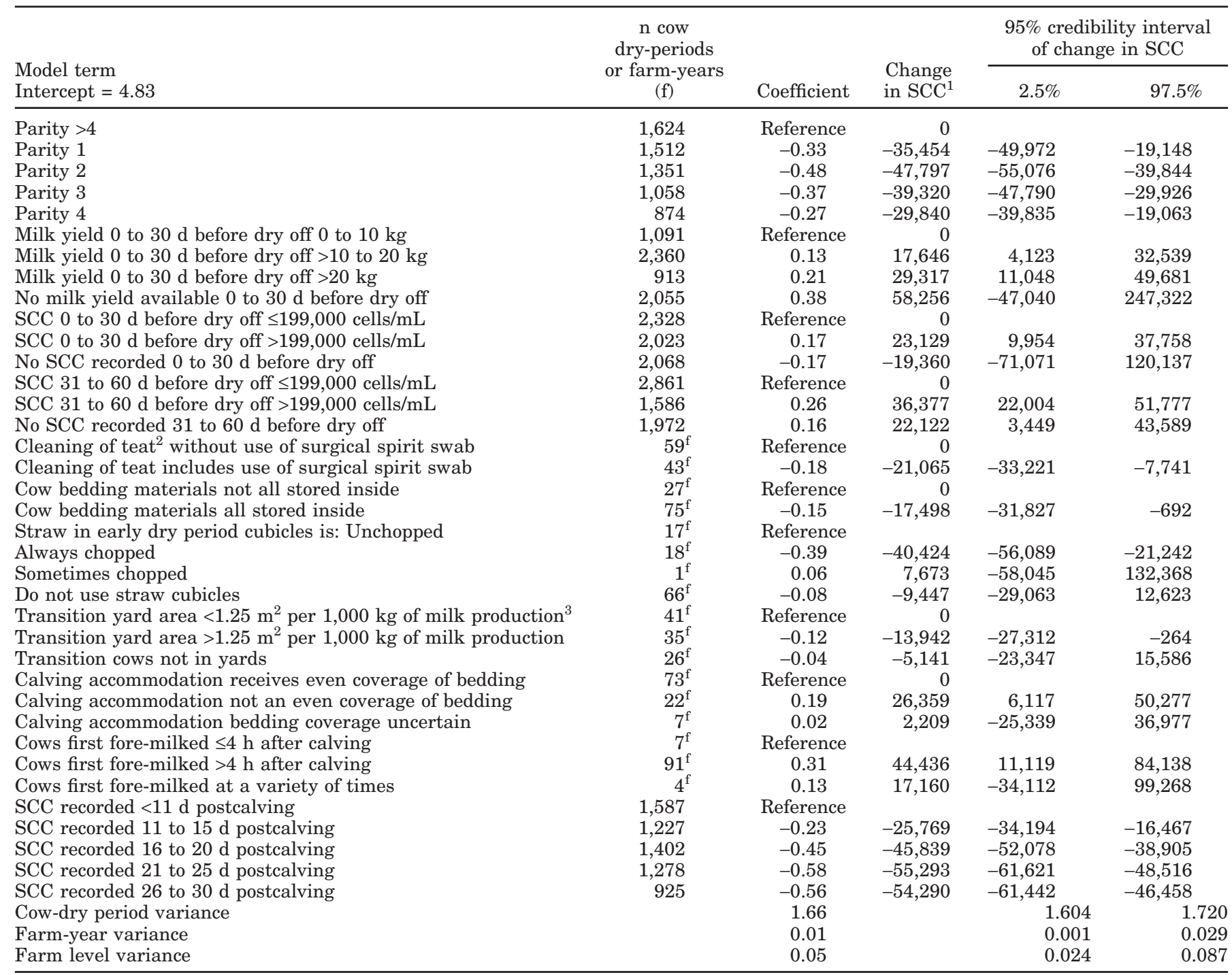

${ }^{1}$ Change in $\mathrm{SCC}=$ difference to the model mean of 125,462 cells $/ \mathrm{mL}$.

${ }^{2}$ Cleaning of teat $=$ cleaning before administering dry cow treatments.

${ }^{3}$ Milk production $=$ herd annual mean milk produced per cow.

management factors were applicable and these were considered to be different biological processes. Cows that had a split dry period (partly housed and partly at pasture) were analyzed in different ways. First, they were omitted from the analyses altogether; second, they were included as subjects in both categories; and third, they were included in both categories but with an indicator variable "part housed/pasture". No differences in model interpretation occurred between these methods, and the latter method was chosen to estimate final model parameters. Cows calving for the first time were included in the analysis with precalving milk and SCC data categorized as "not recorded".

\section{Statistics and Analysis}

Cow and farm data were transferred to a database (Microsoft Access 2003, Microsoft Corporation, Redmond, WA) and fields checked for unlikely or impossible entries. Data fields were coded as categorical or continuous as appropriate and data transformations carried out for continuous data to normalize variables when necessary. Cow and farm data were combined such that relevant farm information was related to the correct cow-dry period.

The outcome variables of interest were $\ln (\mathrm{SCC} / 1,000$; normal response) and HighSCC, a binary indicator of 
Table 2. Parameter estimates from the multilevel Bernoulli model with SCC $>199,000$ cells $/ \mathrm{mL}$ within $30 \mathrm{~d}$ of calving as the response, for cows housed during the dry period (model 2)

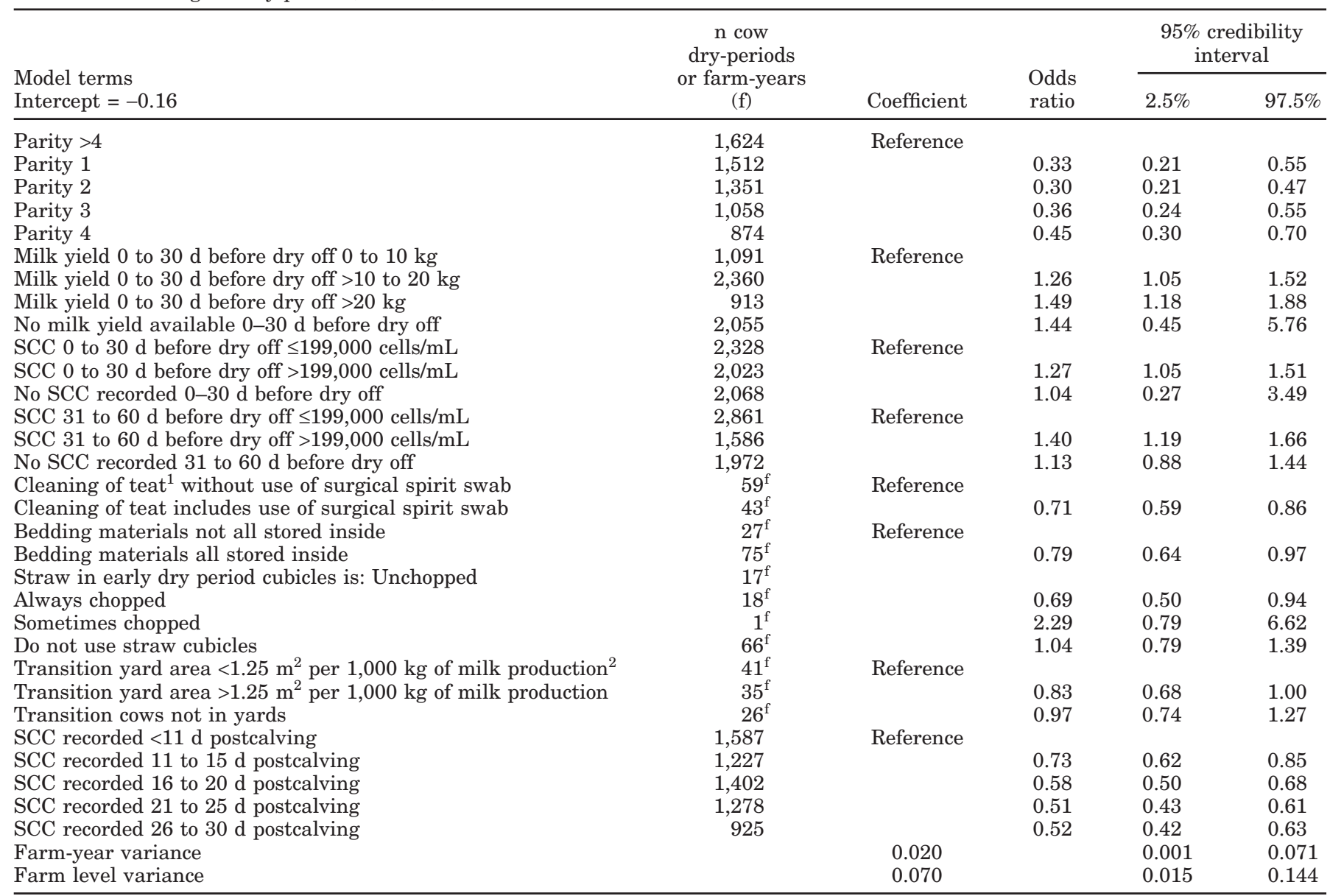

${ }^{1}$ Cleaning of teat $=$ cleaning before administering dry cow treatments.

${ }^{2}$ Milk production $=$ herd annual mean milk produced per cow.

whether SCC $>199,000$ cells/mL or not, for cow SCC within $30 \mathrm{~d}$ of calving. The data were hierarchical, consisting of an SCC associated with a calving for each cow or heifer (cow-dry period), within a 12-mo period on a farm (farm-year), within a farm. Models were tested with a structure "dry period" within "cow" within "farm", but this provided a poorer model fit to the data and therefore was not used.

Initial analysis consisted of descriptive statistics and graphical assessments. Multilevel (random effects) models (Goldstein, 1995) were specified so that correlations within the data (cow-dry periods within farmyears within farms) were accounted for appropriately. Model specifications were

$$
\text { 1. } \begin{aligned}
\ln \left(\mathrm{SCC}_{\mathrm{ijk}} / 1,000\right)=\alpha+\beta_{1} \mathrm{X}_{\mathrm{ijk}}+\beta_{2} \mathrm{X}_{\mathrm{jk}}+\beta_{3} \mathrm{X}_{\mathrm{k}} \\
+\mathrm{v}_{\mathrm{k}}+\mathrm{u}_{\mathrm{jk}}+\mathrm{e}_{\mathrm{ijk}}, \mathrm{v}_{\mathrm{k}} \sim \mathrm{N}\left(0, \sigma_{\mathrm{v}}^{2}\right), \mathrm{u}_{\mathrm{jk}} \\
\sim \mathrm{N}\left(0, \sigma_{\mathrm{u}}^{2}\right), \mathrm{e}_{\mathrm{ijk}} \sim \mathrm{N}\left(0, \sigma_{\mathrm{e}}^{2}\right)
\end{aligned}
$$

$$
\begin{aligned}
& \text { 2. HighSCC } \left.\mathrm{ijk}_{\mathrm{jk}} \sim \text { Bernoulli (probability }=\pi_{\mathrm{ijk}}\right) \\
& \begin{array}{c}
\text { Logit }\left(\pi_{\mathrm{ijk}}\right)=\alpha+\beta_{1} \mathrm{X}_{\mathrm{ijk}}+\beta_{2} \mathrm{X}_{\mathrm{jk}}+\beta_{3} \mathrm{X}_{\mathrm{k}}+\mathrm{v}_{\mathrm{k}} \\
+\mathrm{u}_{\mathrm{jk}}, \mathrm{v}_{\mathrm{k}} \sim \mathrm{N}\left(0, \sigma_{\mathrm{v}}^{2}\right), \mathrm{u}_{\mathrm{jk}} \sim \mathrm{N}\left(0, \sigma_{\mathrm{u}}^{2}\right)
\end{array}
\end{aligned}
$$

where the subscripts i, $\mathrm{j}$, and $\mathrm{k}$ denote the ith cow-dry period, the jth farm-year of study and the kth farm, respectively, $\alpha$ the regression intercept, $\mathrm{X}_{\mathrm{ijk}}$ the vector of covariates at cow level, $\beta_{1}$ the coefficients for covariates $\mathrm{X}_{\mathrm{ijk}}, \mathrm{X}_{\mathrm{jk}}$ the vector of farm-year level covariates, $\beta_{2}$ the coefficients for covariates $X_{\mathrm{jk}}, \mathrm{X}_{\mathrm{k}}$ the vector of farm level covariates, $\beta_{3}$ the coefficients for covariates $\mathrm{X}_{\mathrm{k}}, \mathrm{v}_{\mathrm{k}}$ the random effect to reflect residual variation between farms, $\mathrm{u}_{\mathrm{jk}}$ the random effect to reflect residual variation between farm-years, and $\mathrm{e}_{\mathrm{ijk}}$ the random effect to reflect residual variation between cow-dry periods.

The distributions of covariates were assessed and transformations or recategorisation carried out as deemed appropriate on biological grounds. Each of the 
Table 3. Parameter estimates from the multilevel model with $\log (\mathrm{SCC} / 1,000)$ as the response, for cows at pasture during the dry period (model 3)

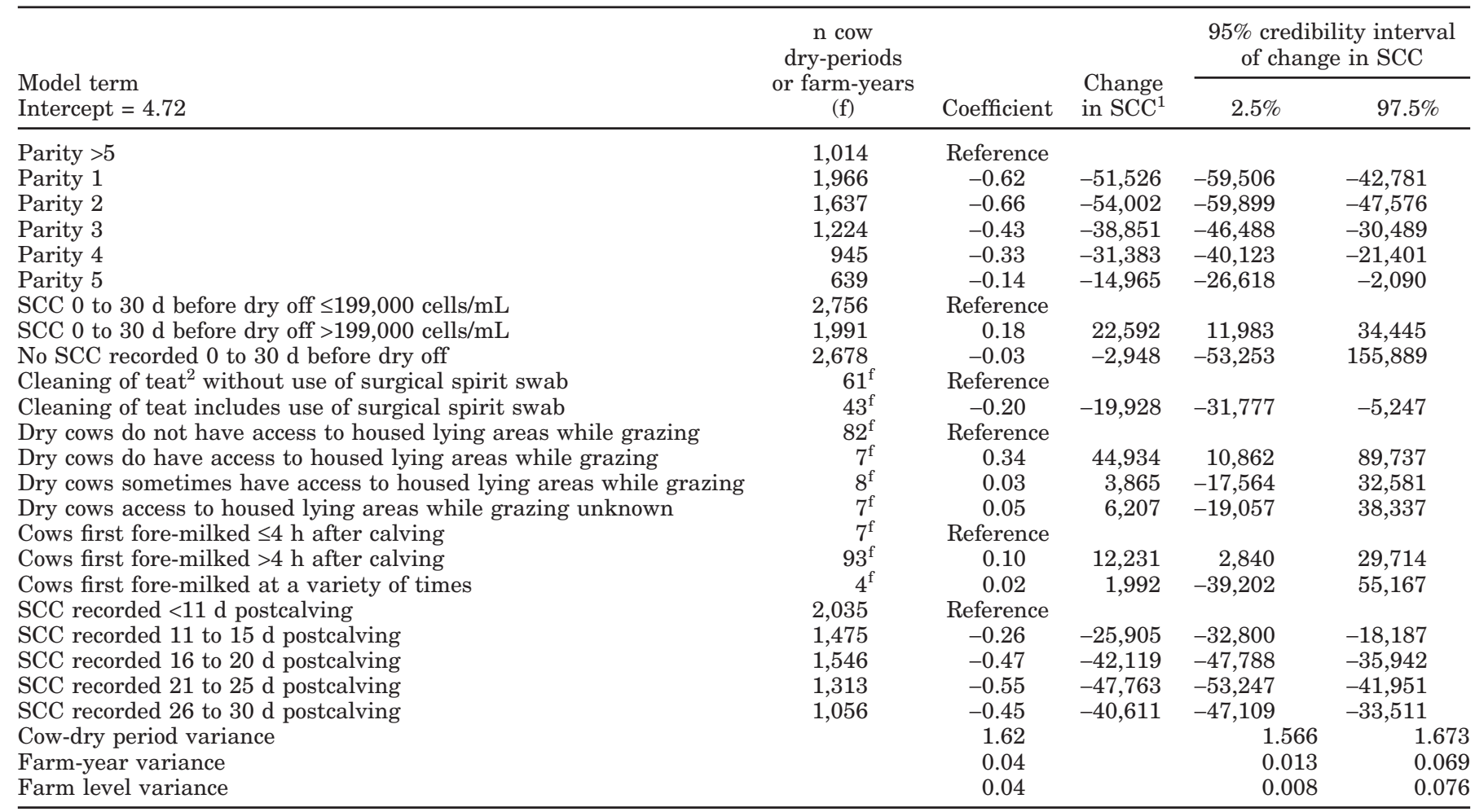

${ }^{1}$ Change in SCC = difference to the model mean of 112,168 cells $/ \mathrm{mL}$.

${ }^{2}$ Cleaning of teat $=$ cleaning before administering dry cow treatments.

350 covariates were examined individually, within the specified model framework, to investigate individual associations with SCC while accounting for the data structure. The covariates SCC at each of the 3 monthly test day readings before drying off were investigated as (logged) continuous fixed effects and also as categorical fixed effects. Exclusive categories, each increasing by 20,000 cells $/ \mathrm{mL}$, were examined, and a threshold SCC of $>199,000$ cell $/ \mathrm{mL}$ provided the best model fit. Therefore, for model parsimony, the final models used this category only. Initial covariate assessment was carried out using MLwiN with penalized quasi-likelihood for parameter estimation (Rasbash et al., 2005). Final models were selected using Markov chain Monte Carlo (MCMC) for parameter estimation in WinBUGS (Spiegelhalter et al., 2004) to avoid the potential biased estimates that can arise from quasi-likelihood methods with binary data (Browne and Draper, 2006). Covariates remained in the model when the $95 \%$ credibility intervals for the odds ratios did not include 1.00. The deviance information criteria (Spiegelhalter et al., 2002), a method that takes into account improved model fit (reduction in deviance) and the increased model complexity (effective number of parameters), was used to inform model selection.
All of the MCMC analyses reported in this paper used a burn-in of at least 2,000 iterations during which time model convergence had occurred. Parameter estimates were based on a minimum further 8,000 iterations. Investigation of model fit was made from plots of residuals in the normal response models and from plots of cumulated fitted probabilities and residuals in the Bernoulli response models (Langford and Lewis, 1998; Green et al., 2004). Comprehensive details of MCMC modeling (Gilks et al., 1996; Spiegelhalter et al., 2004), methods adopted for this research (Green et al., 2004; Browne and Draper, 2006), and the procedures implemented for model selection (Green et al., 2007a) have been described in detail previously.

To further assess model fit and value, predictions were made of $\ln (\mathrm{SCC} / 1,000)$ within $30 \mathrm{~d}$ of calving, using posterior predictive assessments (Gelman et al., 1996). This method uses the full model posterior predictive distribution, as follows:

$$
\begin{gathered}
\text { PREDICTED } \operatorname{SCC}_{\mathrm{ijk}} \sim \mathrm{N}\left(\text { mean }=\mathrm{P}_{\mathrm{ijk}}, \text { variance }=\sigma_{\mathrm{e}}^{2}\right) \\
\mathrm{P}_{\mathrm{ijk}}=\alpha+\beta_{1} \mathrm{X}_{\mathrm{ijk}}+\beta_{2} \mathrm{X}_{\mathrm{jk}}+\beta_{3} \mathrm{X}_{\mathrm{k}}+\mathrm{v}_{\mathrm{k}}+\mathrm{u}_{\mathrm{jk}},
\end{gathered}
$$

where PREDICTED SCC $_{i j k}$ is a draw from a Normal distribution with mean $\mathrm{P}_{\mathrm{ijk}}$ and variance $\sigma^{2}$, and $\mathrm{P}_{\mathrm{ijk}}$ 
Table 4. Parameter estimates from the multilevel Bernoulli model with SCC $>199,000$ cells $/ \mathrm{mL}$ within $30 \mathrm{~d}$ of calving as the response, for cows at pasture during the dry period (model 4)

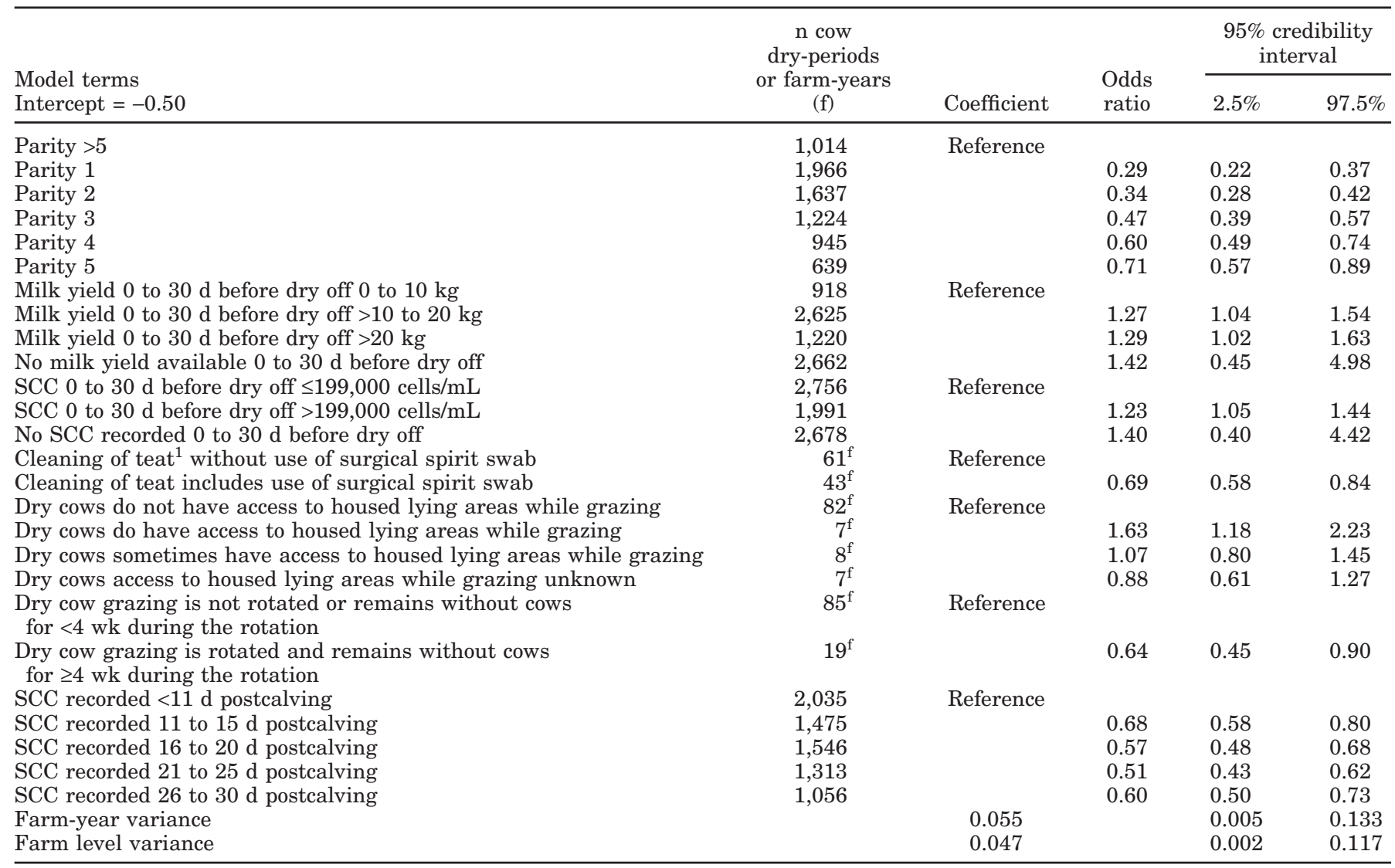

${ }^{1}$ Cleaning of teat $=$ Cleaning before administering dry cow treatments.

is the $\ln (\mathrm{SCC} / 1,000)$ within $30 \mathrm{~d}$ of calving, for cow-dry period $i$ in farm year $j$ on farm $k$, estimated from the model parameters and data. All other parameters are described previously (equation [1]). After model convergence, at each iteration of the MCMC process, the values of PREDICTED SCC ijk $_{\text {were sampled and averaged }}$ across each farm-year, thus providing a posterior prediction of the mean $\ln (\mathrm{SCC} / 1,000)$ within $30 \mathrm{~d}$ of calving, for individual farm-years. Posterior predictions for $\ln (\mathrm{SCC} / 1,000)$ were also made for cows of different parity and different SCC status at the end of the lactation prior to the dry period. Predicted mean $\ln (\mathrm{SCC} / 1,000)$ were then compared with the observed data and displayed graphically to illustrate model performance. An equivalent approach was taken for the Bernoulli response model (SCC $>199,000$ cells $/ \mathrm{mL}$ ), and this method has been described in detail previously (Green et al., 2007a).

The capability of each model to identify farm-years with a high incidence of cows with an SCC $>199,000$ cells $/ \mathrm{mL}$ (specified as a rate $>0.2$ cases per cow), was estimated by calculating the positive and negative pre- dictive values (Dohoo et al., 2003) of the model for each outcome.

\section{RESULTS}

A total of 6,419 cow-dry periods $(5,383$ cows $)$ were used in the analysis of SCC in cows housed for the dry period and 7,425 cow-dry periods $(6,056$ cows $)$ in the analysis of SCC in cows with dry periods at pasture. In yr 1 of the study, 2 farms did not have any cows housed during the dry period available for analysis, and therefore there were 104 farm-years included with cows at pasture during the dry period and 102 farm-years with cows housed. The mean, geometric mean, and median cow SCC within $30 \mathrm{~d}$ of calving for farm-years when cows were housed during the dry period were $273,000,91,000$, and 71,000 cells $/ \mathrm{mL}$, respectively. The mean, geometric mean, and median cow SCC within 30 $\mathrm{d}$ of calving for farm-years when cows were at pasture during the dry period were $237,000,79,000$, and 63,000 cells $/ \mathrm{mL}$, respectively. The arithmetic mean cow SCC within $30 \mathrm{~d}$ of calving tended to rise as the proportion 
of cow SCC $>199,000$ cells $/ \mathrm{mL}$ increased, and this is illustrated for farm-years when cows were housed or at pasture during the dry period (Figures 3 and 4). There was no clear relationship between the proportion of cow SCC $>199,000$ cells $/ \mathrm{mL}$ within $30 \mathrm{~d}$ of calving, for cows housed and those at pasture (Figure 5).

\section{Models of Somatic Cell Counts}

The final models are presented in Tables 1 to 4 . Three cow-level covariates were associated with an increased SCC in all models: parity, an SCC $>199,000$ cells $/ \mathrm{mL}$ in the last $60 \mathrm{~d}$ of the previous lactation, and fewer DIM after calving at the time of the SCC recording. An increased milk yield before drying off was associated with increased SCC after calving in 3 of the 4 models.

At farm level, factors associated with changes in SCC could be classified according to the timing of the event: factors at drying off, in the early dry period, in the late (transition) dry period, and in the calving period. An illustration of the main significant risk factors that summarize all models is provided in Figure 6. No significant effect on SCC in early lactation was identified between different classes of antibiotic dry cow therapy or between antibiotic therapy and internal teat sealants.

\section{Model Predictions}

The farm-year posterior predictions for mean ln (SCC/1,000) and proportion of cows with SCC $>199,000$ cells/mL were good (Figures 7 to 10). These predictions explained over $74 \%$ of the variability in the observed farm-year level data in each model. Similarly, posterior predictions for $\ln (\mathrm{SCC} / 1,000)$ for cows of different parity and SCC status (Figures 11 and 12) displayed a good fit to the observed data, with the observed mean SCC for each group being well within the $95 \%$ credibility interval of the posterior predicted mean SCC.

The positive and negative predictive values for identifying farm-years with an incidence rate of cow SCC > 199,000 cells $/ \mathrm{mL}$ of $>0.2$ cases per cow, when cows were housed during the dry period, were 81.3 and $90.1 \%$, respectively. The equivalent positive and negative predictive values for farm-years when cows were at pasture were 85.9 and $90.0 \%$.

\section{DISCUSSION}

This is the second recent UK study to investigate cow characteristics, farm facilities, and herd management strategies during the dry period in relation to mammary gland health in the next lactation (Green et al., 2007a). There are broad similarities but also some differences between the previous study of clinical mastitis and the current study of SCC. The general conclusion that both cow and herd factors through the dry period are important in determining mammary gland health early in the next lactation can be drawn from both studies. In both cases, significant factors were identified at drying off, in the early and late dry period, and at calving.

Previous research focusing on parity-one cows has also identified management factors that influence SCC after calving although these included aspects of feeding, housing, herd prevalence of high SCC cows, and herd milk yield that were different to significant covariates identified in this study (De Vliegher et al., 2004b; Svensson et al., 2006). This suggests that management strategies important for determining SCC after calving may vary between different populations, and it may therefore be important to undertake this type of research in different countries or environments.

In addition to parity and SCC in the previous lactation, cow characteristics associated with an increased SCC after calving in this study were increased milk yield in the $30 \mathrm{~d}$ before drying off and reduced length of time from calving to SCC estimation. These associations have been reported previously (Barkema et al., 1999; Osterås and Edge, 2000; Rajala-Schultz et al., 2005; Whist and Osterås, 2006), although interestingly increased milk yield before drying off was not identified as a significant risk factor when clinical mastitis was investigated in these herds (Green et al., 2007a). Reducing cow milk yield by reducing the plane of nutrition in the weeks before drying off currently appears to be a pragmatic recommendation, and in this study a yield below $10 \mathrm{~kg}$ was associated with lowest SCC in the subsequent lactation. The reason an SCC >199,000 cell $\mathrm{s} / \mathrm{mL}$ before drying off increased the risk of a raised SCC in the subsequent lactation is likely to be because some existing infections are not cured during the dry period or because a high SCC is a marker for a susceptible cow.

Most of the herd management factors associated with increased SCC in the first $30 \mathrm{~d}$ of lactation were associated with hygiene measures or environmental management and can be readily implemented. The use of surgical spirit swabbing before administration of dry cow treatments has been recommended in the United Kingdom (Bradley et al., 2002), and this procedure was associated with a significant reduction in SCC in each model. This is in agreement with a previous study that reported that disinfection of teat ends with alcohol before intramammary infusion at dry off was more likely to be practiced in herds with very low rather than medium SCS (Barnouin et al., 2004). The reason for this is presumably through a reduced probability of bacterial 
Cows of lower parity

Cow bedding materials all stored inside

SCC $\leq 199,000$ cells $/ \mathrm{mL} 0$ to $60 \mathrm{~d}$ before dry off

Yield at test day 0-30 d before drying off $<10 \mathrm{~kg}$

Cleaning of teat includes use of surgical spirit swab before administration of dry treatments

Straw in early dry period cubicles is chopped

Transition yard area $>1.25 \mathrm{~m}^{2}$ per $1,000 \mathrm{~kg}$ annual mean cow milk production

Dry cows do not have access to housed lying areas while grazing

Dry cow grazing is rotated and remains without cows for $\geq 4$ wk during the rotation

\section{Calving accommodation receives even coverage of} bedding

\section{Cows first fore-milked $\leq 4 \mathrm{~h}$ after calving}

Overall Factors

Previous Lactation

Drying Off

Early Dry Period

Late Dry Period

General Dry Period

Calving Period

Figure 6. Summary of the major cow, farm and management factors associated with reduced SCC in the first $30 \mathrm{~d}$ of lactation.

entry to the mammary gland during application of a treatment.

It is noteworthy that no particular types or regimens of dry cow treatment used in a herd, whether antibiotic therapies or internal teat sealants, were associated with a significant difference in SCC after calving. Thus, this study provided no evidence that internal sealants performed differently to antibiotic therapy when judged by SCC in early lactation. The median herd proportion of cows in a farm-year with SCC $>199,000$ cells $/ \mathrm{mL}$ in 


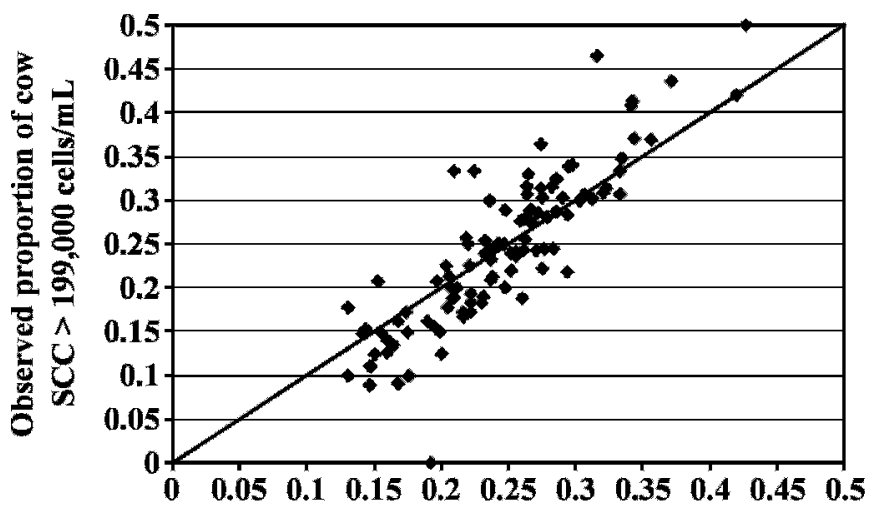

Predicted proportion of cow SCC $>199,000$ cells $/ \mathrm{mL}$

Figure 7. Correlation between model posterior prediction and the observed proportion of cows with SCC $>199,000$ cells $/ \mathrm{mL}$ in the first $30 \mathrm{~d}$ of lactation, for the 102 farm-years with cattle housed during the dry period $\left(\mathrm{R}^{2}=74.1 \%\right)$.

the first $30 \mathrm{~d}$ of lactation was relatively high ( $>0.2$ cases per cow), and this was despite the use of dry cow treatments in virtually all cows (of parity greater than 1). This suggests that aspects of management other than the dry cow product are important in determining SCC in the first $30 \mathrm{~d}$ of lactation. There were insufficient numbers of cows that received no dry cow treatment for the effect of no treatment to be evaluated.

Reduced stocking density during housing and increased rest of pasture between grazing periods were associated with reduced SCC after calving. A possible reason for this is reduced bacterial contamination of the environment and thus reduced exposure of cows to pathogens. Stocking density for cows housed in straw

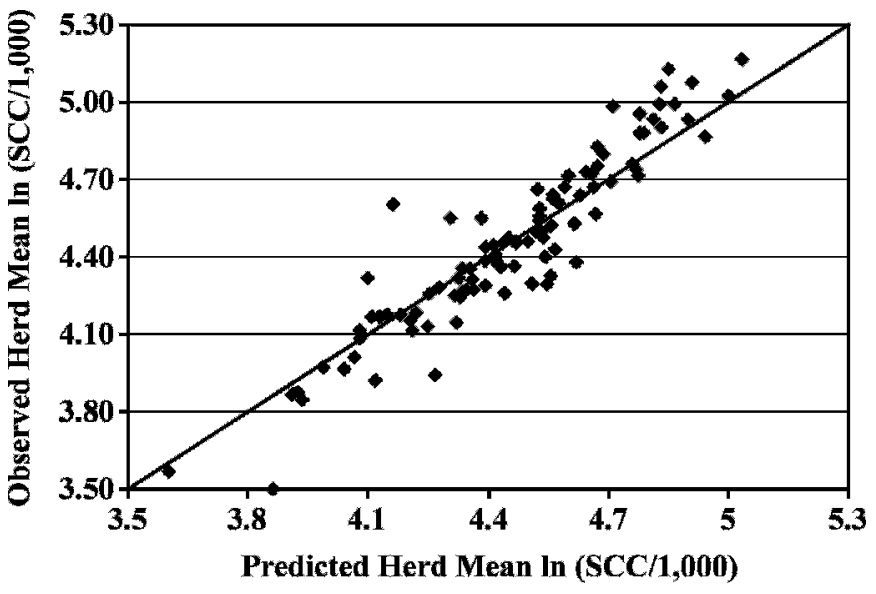

Figure 8. Correlation between model posterior prediction and the observed herd mean $\ln (\mathrm{SCC} / 1,000)$, in the first $30 \mathrm{~d}$ of lactation, for the 102 farm-years when cattle were housed during the dry period $\left(\mathrm{R}^{2}=87.0 \%\right)$.

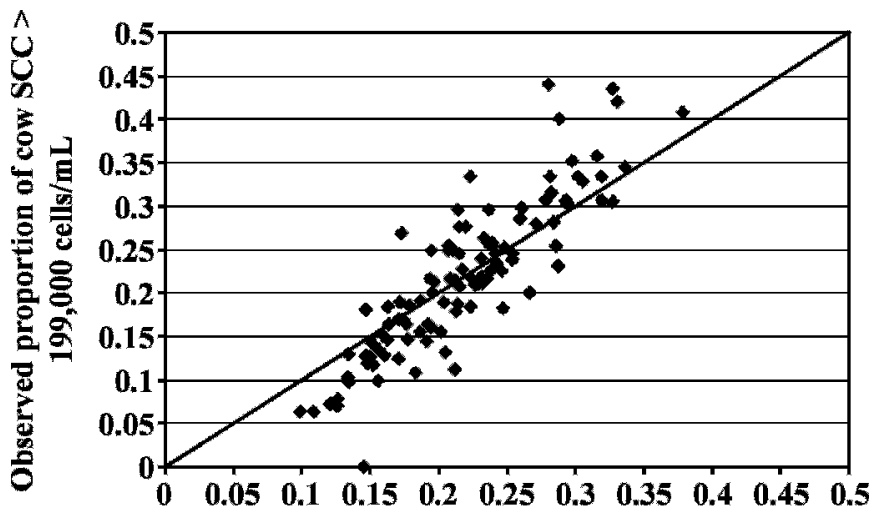

Predicted proportion of cow SCC $>199,000 \mathrm{cells} / \mathrm{mL}$

Figure 9. Correlation between model posterior prediction and the observed proportion of cows with SCC $>199,000$ cells $/ \mathrm{mL}$ in the first $30 \mathrm{~d}$ of lactation, for the 104 farm-years with cattle at pasture during the dry period $\left(\mathrm{R}^{2}=75.2 \%\right)$.

yards in the United Kingdom is often recommended to be 6 to $8 \mathrm{~m}^{2}$ lying area per cow. Results of this study suggest that increasing this allowance may be beneficial for mastitis control with $10 \mathrm{~m}^{2}$ per cow (for herds with a mean annual milk yield per cow of $8,000 \mathrm{~kg}$ ) or $12.5 \mathrm{~m}^{2}$ per cow (for herds with a mean annual milk yield per cow of $10,000 \mathrm{~kg}$ ) being an appropriate space allowance.

Two cow characteristics (parity and SCC in the previous lactation) and 2 herd management factors (rotation of dry cow pasture and the time after calving until cows were first fore-milked) that were found to be significant predictors for raised SCC were also identified as significant factors for clinical mastitis in the previous

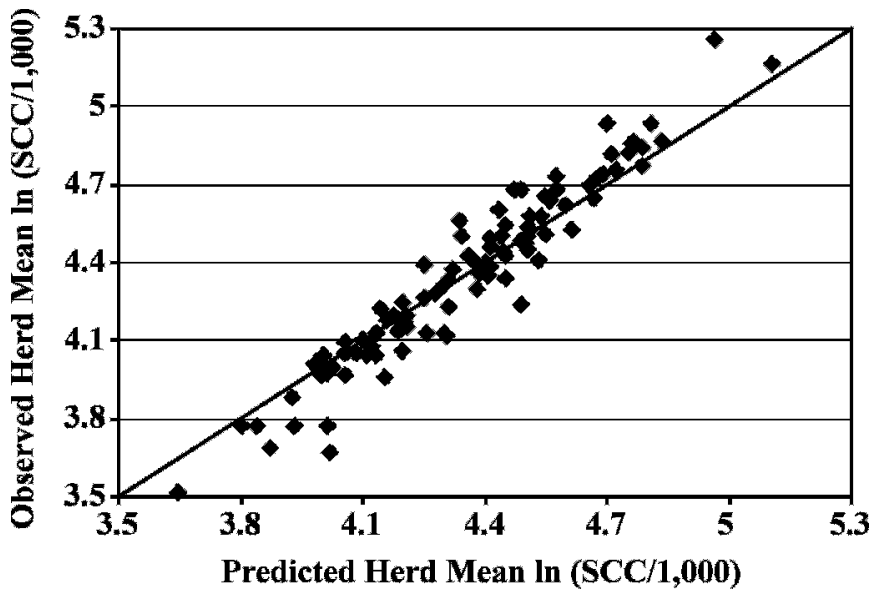

Figure 10. Correlation between model posterior prediction and the observed herd mean $\ln (\mathrm{SCC} / 1,000)$, in the first $30 \mathrm{~d}$ of lactation, for the 104 farm-years when cattle were at pasture during the dry period $\left(\mathrm{R}^{2}=93.4 \%\right)$. 


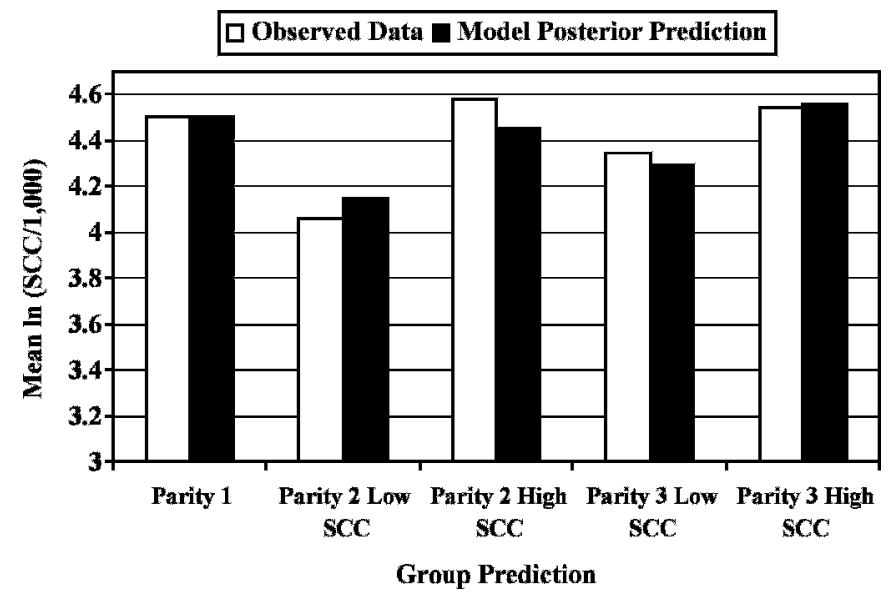

Figure 11. Model posterior predictions and observed data for mean ln (SCC/1,000), in the first $30 \mathrm{~d}$ of lactation, for groups of cows of different parity, which were housed during the dry period. Low SCC refers to cows with no SCC $>199,000$ cells/mL 0 to $60 \mathrm{~d}$ before dry off and high SCC refers to cows with at least one SCC >199,000 cells/ $\mathrm{mL} 0-60 \mathrm{~d}$ before dry off.

study on these herds (Green et al., 2007a). The reason for a reduced time after calving until cows were first fore-milked (milk stripped and checked manually by a herdsperson) being protective is uncertain. A possible explanation could be a flushing effect, pathogens being removed by fore-stripping before an infection establishes. The other specific determinants identified for raised SCC were different to those previously reported for clinical mastitis. For instance, significant predictors

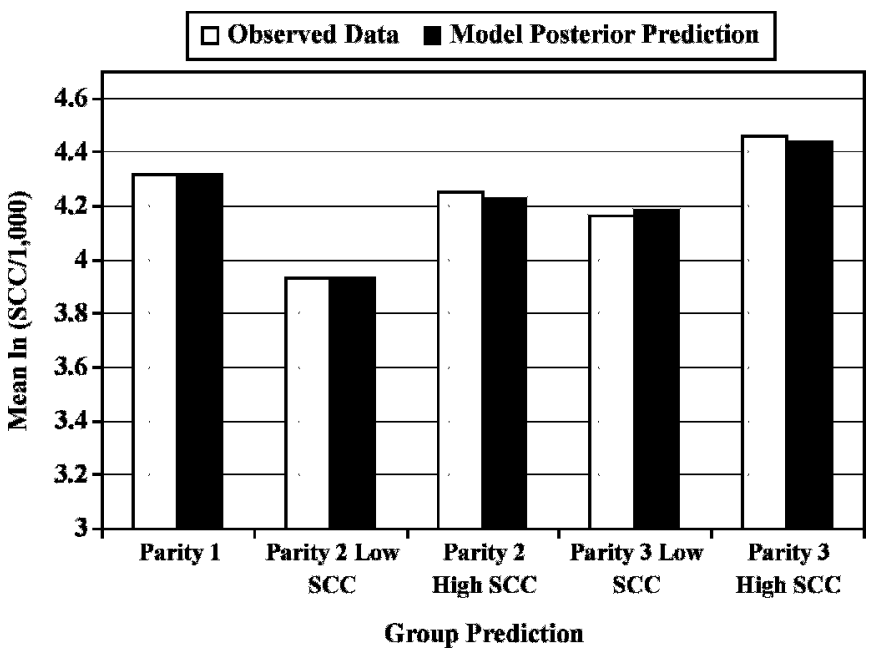

Figure 12. Model posterior predictions and observed data for mean ln (SCC/1,000), in the first $30 \mathrm{~d}$ of lactation, for groups of cows of different parity, which were at pasture during the dry period. Low SCC refers to cows with no SCC $>199,000$ cells $/ \mathrm{mL} 0$ to $60 \mathrm{~d}$ before dry off and high SCC refers to cows with at least one SCC $>199,000$ cells/mL 0 to $60 \mathrm{~d}$ before dry off. of clinical mastitis not found to be associated with raised SCC were the approach to dry cow treatments (individual cow as opposed to whole herd), the use of a Leptosporosis vaccine, and nutrition-related factors such as body condition scores and method of forage provision. Differences in dry period determinants for clinical mastitis and SCC may reflect different causal pathways involved, such as different pathogen involvement or a different influence of cow immune status. To optimize mammary gland health, determinants for both clinical mastitis and SCC need to be addressed on an individual unit.

There was considerable variation in the length of dry period among the cows in this study (mean $=65.9 \mathrm{~d}$, median $=59.0 \mathrm{~d}$, interquartile range $=51$ to $71 \mathrm{~d}$ ), but it is of interest that the length of dry period was not found to be associated with changes in SCC after calving [nor previously with the occurrence of clinical mastitis after calving (Green et al., 2007a)]. There has been recent interest in reducing the length of the dry period (Gumen et al., 2005; Rastani et al., 2005), but this research suggests that, in terms of mammary gland health, herd management and cow factors are more important than the length of the dry period.

The residual plots and posterior predictions of SCC made from the final models indicated that model fit was good. Posterior predictions are a useful technique to assessment model fit and validity and are easily implemented in a Bayesian framework (Gelman et al., 1996). Residual (unexplained) variation in the Normal response models was greatest at cow-dry period level and relatively small at farm-year and farm level. Thus, whereas predictions from the models were accurate for the mean SCC of groups of cows (for example across farm-years or for different parities), they were less good for individual cows. This phenomenon has been reported previously using similar statistical models of SCC in parity one cows after calving (De Vliegher, 2004b). Predictions on an individual cow basis are necessarily complex and would need to incorporate individual cow components such as genetic, environmental, and immune information and these are often unknown or difficult to specify. For example, within a generally poor farm environment, a high proportion of cows may get an IMI, but it is difficult to determine which cows use the environment in a way that may increase their individual risk of infection. However, in this research, the aim was to predict an overall risk for cows within a herd so as to identify aspects of management that could improve prevention.

There is now useful information from the current and previous studies to indicate that cow and herd factors during the dry period are important in determining mammary gland health after calving. Individual farms 
can assess their own areas of risk and make appropriate changes. Herds with a relatively high incidence of clinical mastitis or cows with $\mathrm{SCC}>199,000$ cell $/ \mathrm{mL}$ within $30 \mathrm{~d}$ of calving have considerable scope for improvement through application of appropriate management practices.

\section{CONCLUSIONS}

Combinations of cow characteristics, farm facilities, and herd management strategies during the dry period were associated with an increased SCC in early lactation. The research indicated that dry period management influences SCC in the next lactation and has highlighted areas important for mastitis control.

\section{ACKNOWLEDGMENTS}

This research was funded by the Wellcome Trust; Martin Green is a Wellcome Trust Intermediate Clinical Fellow. We would like to thank the Milk Development Council for funding the initial research and NMR for providing data. We are also very grateful to Laura Green (Univ. Warwick), James Breen (Univ. Bristol), and Katharine Leach (Univ. Bristol) who were involved with data collection, James Booth (Milk Development Council) for his support, and all the farmers and their veterinary surgeons for their participation and cooperation.

\section{REFERENCES}

Barkema, H. W., H. A. Deluyker, Y. H. Schukken, and T. J. Lam. 1999. Quarter-milk somatic cell count at calving and at the first six milkings after calving. Prev. Vet. Med. 38:1-9.

Barnouin, J., M. Chassagne, S. Bazin, and D. Boichard. 2004. Management practices from questionnaire surveys in herds with very low somatic cell score through a national mastitis program in France. J. Dairy Sci. 87:3989-3999.

Bradley, A. J., and M. J. Green. 2005. Use and interpretation of somatic cell count data in dairy cows. In Pract. 27:310-315.

Bradley, A. J., M. J. Green, and J. N. Huxley. 2002. Making better use of milk samples: Monitoring and investigating herd mastitis. Cattle Pract. 10:105-112.

Brolund, L. 1985. Cell counts in bovine milk. Causes of variation and applicability for diagnosis of subclinical mastitis. Acta Vet. Scand. 80:1-123.

Browne, W. J., and D. Draper. 2006. A comparison of Bayesian and likelihood-based methods for fitting multilevel models. Bayesian Analysis 1:473-514.

Cook, N. B., T. B. Bennett, K. M. Emery, and K. V. Nordlund. 2002. Monitoring nonlactating cow intramammary infection dynamics using DHI somatic cell count data. J. Dairy Sci. 85:1119-1126.

De Vliegher, S., H. W. Barkema, G. Opsomer, A. de Kruif, and L. Duchateau. 2005a. Association between somatic cell count in early lactation and culling of dairy heifers using Cox frailty models. J. Dairy Sci. 88:560-568.

De Vliegher, S., H. W. Barkema, H. Stryhn, G. Opsomer, and A. de Kruif. 2004a. Impact of early lactation somatic cell count in heifers on somatic cell counts over the first lactation. J. Dairy Sci. 87:3672-3682.
De Vliegher, S., H. W. Barkema, H. Stryhn, G. Opsomer, and A. de Kruif. 2005b. Impact of early lactation somatic cell count in heifers on milk yield over the first lactation. J. Dairy Sci. 88:938-947.

De Vliegher, S., H. Laevens, H. W. Barkema, I. R. Dohoo, H. Stryhn, and G. Opsomer. 2004b. Management practices and heifer characteristics associated with early lactation somatic cell count of Belgian dairy heifers. J. Dairy Sci. 87:937-947.

Dingwell, R. T., K. E. Leslie, Y. H. Schukken, J. M. Sargeant, L. L. Timms, T. F. Duffield, G. P. Keefe, D. F. Kelton, K. D. Lissemore, and J. Conklin. 2004. Association of cow and quarter-level factors at drying-off with new intramammary infections during the dry period. Prev. Vet. Med. 63:75-89.

Dohoo, I. R., and K. E. Leslie. 1991. Evaluation of changes in somatic cell counts as indicators of new intramammary infections. Prev. Vet. Med. 10:225-237.

Dohoo, I. R., W. Martin, and H. Stryhn. 2003. Veterinary Epidemiologic Research. AVC Inc., Charlottetown, Canada.

Dohoo, I. R., and A. H. Meek. 1982. Somatic cell counts in bovine milk. Can. Vet. J. 23:119-125.

Gelman, A., X. L. Meng, and H. Stern. 1996. Posterior predictive assessment of model fitness via realized discrepancies. Stat. Sinica 6:733-807.

Gilks, W. R., S. Richardson, and D. J. Spiegelhalter. 1996. Markov Chain Monte Carlo in Practice. Chapman and Hall, London, UK.

Goldstein, H. 1995. Multilevel Statistical Models. 2nd ed. Edward Arnold, London, UK.

Green, M. J., A. J. Bradley, G. F. Medley, and W. J. Browne. 2007a. Cow, farm and management factors during the dry period that determine the rate of clinical mastitis after calving. J. Dairy Sci. 90:3764-3776.

Green, M. J., A. J. Bradley, H. Newton, and W. J. Browne. 2006. Seasonal variation of bulk milk somatic cell counts in UK dairy herds: Investigations of the summer rise. Prev. Vet. Med. 74:293-308.

Green, M. J., P. R. Burton, L. E. Green, Y. H. Schukken, A. J. Bradley, E. J. Peeler, and G. F. Medley. 2004. The use of Markov chain Monte Carlo for analysis of correlated binary data: Patterns of somatic cells in milk and the risk of clinical mastitis in dairy cows. Prev. Vet. Med. 64:157-174.

Green, M. J., L. E. Green, A. J. Bradley, P. R. Burton, Y. H. Schukken, and G. F. Medley. 2005. Bacterial isolates in the dry bovine mammary gland. Prevalence and Associations. Vet. Rec. 156:71-77.

Green, M. J., K. A. Leach, J. E. Breen, L. E. Green, and A. J. Bradley. 2007b. A national intervention study of mastitis control on dairy herds in England and Wales. Vet. Rec. 160:287-293.

Gumen, A., R. R. Rastani, R. R. Grummer, and M. C. Wiltbank. 2005. Reduced dry periods and varying prepartum diets alter postpartum ovulation and reproductive measures. J. Dairy Sci. 88:2401-2411.

Huijps, K., and H. Hogeveen. 2007. Stochastic modeling to determine the economic effects of blanket, selective, and no dry cow therapy. J. Dairy Sci. 90:1225-1234.

Laevens, H., H. Deluker, Y. H. Schukken, L. de Meulemeester, R. Vandermeersch, E. de Muelenaere, and A. de Kruif. 1997. Influence of parity and stage of lactation on the somatic cell count in bacteriologically negative dairy cows. J. Dairy Sci. 80:3219-3226.

Langford, I. H., and T. Lewis. 1998. Outliers in Multilevel Data. J. R. Stat. Soc. A 161:121-160.

Lievaart, J. J., H. W. Barkema, W. D. Kremer, J. van den Broek, J. H. Verheijden, and J. A. Heesterbeek. 2007. Effect of herd characteristics, management practices, and season on different categories of the herd somatic cell count. J. Dairy Sci. 90:41374144 .

McDermott, M. P., H. N. Erb, and R. P. Natzke. 1982. Predictability by somatic cell counts related to prevalence of intramammary infection within herds. J. Dairy Sci. 65:1535-1539.

McDougall, S. 2003. Management factors associated with the incidence of clinical mastitis over the non-lactation period and bulk tank somatic cell count during the subsequent lactation. N. Z. Vet. J. 2:63-72. 
Osterås, O., and V. L. Edge. 2000. Factors prior to dry period associated with high and low levels of cow milk somatic cell counts in next lactation. Acta Vet. Scand. 41:63-77.

Rajala-Schultz, P. J., J. S. Hogan, and K. L. Smith. 2005. Association between milk yield at dry-off and probability of intramammary infections at calving. J. Dairy Sci. 88:577-579.

Rasbash, J., W. J. Browne, M. Healy, B. Cameron, and C. Charlton. 2005. MLwiN Version 2.02. Mulilevel Models Project, Institute of Education, London, UK.

Rastani, R. R., R. R. Grummer, S. J. Bertics, A. Gumen, M. C. Wiltbank, D. G. Mashek, and M. C. Schwab. 2005. Reducing dry period length to simplify feeding transition cows: Milk production, energy balance, and metabolic profiles. J. Dairy Sci. 88:10041014.

Schepers, A. J., T. J. Lam, Y. H. Schukken, J. B. Wilmink, and W. J. Hanekamp. 1997. Estimation of variance components for somatic cell counts to determine thresholds for uninfected quarters. J. Dairy Sci. 80:1833-1840.

Schukken, Y. H., D. J. Wilson, F. Welcome, L. Garrison-Tikofsky, and R. N. Gonzalez. 2003. Monitoring udder health and milk quality using somatic cell counts. J. Dairy Sci. 34:579-596.
Sordillo, L. M., K. Shafer-Weaver, and D. DeRosa. 1997. Immunobiology of the mammary gland. J. Dairy Sci. 80:1851-1865.

Spiegelhalter, D. J., N. G. Best, B. P. Carlin, and A. van der Linde. 2002. Bayesian measures of model complexity and fit (with discussion). J. R. Stat. Soc. Ser. B Stat. Methodol. 64:583-640.

Spiegelhalter, D. J., A. Thomas, and N. Best. 2004. WinBUGS Version 1.4.1. MRC Biostatistics Unit, Cambridge, UK.

Svensson, C., A. K. Nyman, K. Persson Waller, and U. Emanuelson. 2006. Effects of housing, management, and health of dairy heifers on first-lactation udder health in southwest Sweden. J. Dairy Sci. 89:1990-1999.

Wenz, J. R., S. M. Jensen, J. E. Lombard, B. A. Wagner, and R. P. Dinsmore. 2007. Herd management practices and their association with bulk tank somatic cell count on United States dairy operations. J. Dairy Sci. 90:3652-3659.

Whist, A. C., and O. Osterås. 2006. Associations between somatic cell counts at calving or prior to drying-off and future somatic cell counts, in the remaining or subsequent lactation. J. Dairy Res. 73:277-287. 